\title{
Minuman Ringan Berkarbonasi Dapat Meningkatkan Keasaman Rongga Mulut
}

\author{
Ni Putu Widani Astuti ${ }^{1}$, Tri Purnami ${ }^{2}$, Cok Gede Agung Kusuma Putra ${ }^{3}$ \\ ${ }^{1}$ Bagian Ilmu Kedokteran Gigi Anak, Fakultas Kedokteran Gigi Universitas Mahasaraswati, Denpasar \\ ${ }^{2}$ Bagian Prostodonsia, Fakultas Kedokteran Gigi Universitas Mahasaraswati, Denpasar \\ ${ }^{3}$ Mahasiswa Tingkat Sarjana, Fakultas Kedokteran Gigi Universitas Mahasaraswati, Denpasar \\ e-mail: putu_widani@yahoo.co.id
}

\begin{abstract}
Soft drinks are beverages that do not contain alcohol (non alcoholic). Soft drinks have a low pH (<5.5). Consuming carbonated soft drinks can cause increased acidity in the oral cavity. The acidity of the oral cavity occurs due to disruption of the saliva buffer system whose function is to resist the decrease in $\mathrm{pH}$ or increase the acidity of the oral cavity. The purpose of this study was to determine the effect of carbonated soft drinks on the acidity of the mouth. Type of research used in this study was quasi-experimental with a pre-test post-test design group approach. This study used a sample of 50 people by using random sampling techniques. All samples consisting of 50 people were asked to accommodate the saliva first and then measured with a pH meter. After that, all samples were instructed to drink soft drinks according to the specified dose $(250 \mathrm{ml})$. Five minutes later all samples were asked to collect the saliva again and then measure it. The results obtained from this study are based on a T-test where the level of significance produced is smaller than 0.05 which states that carbonated soft drinks have a significant effect on the acidity of the oral cavity. The conclusion is carbonated soft drinks can increase the acidity of the oral cavity.
\end{abstract}

Keywords: acidity of the oral cavity, carbonated soft drinks.

\section{PENDAHULUAN}

Dewasa ini masyarakat hidup dalam lingkungan modern yang memiliki gaya hidup serba instan, hal ini terlihat dari meningkatnya kebiasaan dalam mengkonsumsi minuman ringan. Minuman ringan yang beredar di tengah masyarakat sekarang umumnya bersifat asam, salah satu diantaranya yaitu mengandung asam bikarbonat. ${ }^{1}$ Minuman ringan berkarbonasi adalah minuman ringan yang dibuat dengan mengabsorpsi karbondioksida ke dalam air minum, mengandung gas $\mathrm{CO}_{2}$ yang larut dalam air berfungsi sebagai antibakteri untuk mengawetkan minuman secara alami. ${ }^{2}$ Minuman ringan berkarbonat memiliki $\mathrm{pH}$ yang sangat rendah atau dibawah pH kritis yaitu 5,5 sehingga sesudah dikonsumsi dan menyebabkan terjadinya penurunan $\mathrm{pH}$ saliva. ${ }^{3}$ Dalam keadaan normal, rongga mulut selalu dibasahi oleh saliva, saliva di dalam rongga mulut mempunyai $\mathrm{pH}$ yang dapat berubah setiap saat. Penurunan $\mathrm{pH}$ yang berulang ulang dalam waktu tertentu akan mengakibatkan demineralisasi permukaan gigi dan $\mathrm{pH}$ saliva yang rendah dan mencapai suatu angka kritis dapat menyebabkan terjadinya karies gigi. ${ }^{4}$

A. Keasaman rongga mulut

Rongga mulut merupakan pintu masuk utama mikroorganisme, di dalam rongga mulut terdapat beberapa faktor yang terlibat dalam organisasi pertahanan terhadap kuman pathogen dikategorikan menjadi barier anatomi dan fisiologi seperti, epitel, aliran air liur atau anatomi gigi; pertahanan seluler, misalnya fagositosis oleh leukosit dan makrofag; dan imunitas humoral melalui antibodi di dalam air liur dan cairan celah gusi. ${ }^{5,6}$

Saliva atau disebut dengan air liur sangat berperan dalam membersihkan rongga mulut dari mikroorganisme. ${ }^{7}$ Saliva yang merupakan cairan dalam mulut, salah satu fungsinya adalah sebagai buffer yang dapat menjaga kestabilan $\mathrm{pH}$ rongga mulut. Kondisi ini tergantung dari keadaan saliva sendiri apakah viskositas atau volume nya cukup untuk menjaga kestabilan sehingga email, sementum, atau dentin gigi tidak mengalami kelarutan. ${ }^{1,7}$

Saliva mempunyai peranan sebagai buffer dimana naik turunnya $\mathrm{pH}$ dapat ditahan, sehingga proses dekalsifikasi dapat dihambat. ${ }^{7}$ Air liur akan tetap mengalir walaupun tanpa dirangsang, rata-rata sekitar 19 $\mathrm{ml}$ per jam atau sekitar $500 \mathrm{ml}$ per hari. Rata-rata sekeresi meningkat pada saat makan atau karena rangsangan psikis dan menurun pada waktu tidur. Bila jumlah aliran air liur menurun, dapat meningkatkan frekuensi karies gigi, dan keradangan kelenjar parotis. Pada $\mathrm{pH}$ air liur yang rendah, mikroorganisme dapat berkembang dengan baik. Sebaliknya, pada $\mathrm{pH}$ tinggi dapat mencegah terjadinya karies gigi. ${ }^{5,8}$

Senyawa organik yang terkandung di dalam saliva yang mempengaruhi $\mathrm{pH}$ terutama gugus bikarbonat, 
fosfat, asam karbonat, ammonia, dan urea. Kapasitas buffer terutama ditentukan oleh kandungan bikarbonat, sedangkan fosfat, protein, ammonia dan urea merupakan tambahan sekunder pada kapasitas buffer., ${ }^{9,10}$ Ion bikarbonat yang ada di dalam saliva berperan penting untuk proses buffer di dalam saliva. Ion fluoride yang ada di dalam saliva cukup dipengaruhi oleh makanan dan minuman yang dikonsumsi. Kemampuan buffer saliva ditentukan oleh 85\% konsentrasi bikarbonat, 14\% ditentukan oleh konsentrasi fosfat dan $1 \%$ protein saliva. Kadar bikarbonat dalam saliva sebesar 206,97 ppm. ${ }^{7,14}$

B. $\mathrm{pH}$ saliva

Derajat keasaman suatu larutan dinyatakan dengan $\mathrm{pH}, \mathrm{pH}$ saliva yang normal berkisar antara 6,8 hingga 7,4 (Forleo, 2008). Menurut Linder (1991) derajat keasaman saliva dalam keadaan normal antara 5,6 - 7,0 dengan rata-rata $\mathrm{pH}$ 6,7. Dalam rongga mulut, $\mathrm{pH}$ yang rendah dapat memicu mikroorganisme berkembang dengan baik, jika pada $\mathrm{pH}$ yang tinggi, dapat mencegah terjadinya karies ${ }^{5,8}$.

\section{Faktor protektif dalam saliva}

Faktor protektif yang terkandung dalam saliva adalah ion $\mathrm{Ca}$ dan $\mathrm{HPO}_{4}$, bikarbonat yang berfungsi sebagai buffer, aliran saliva, dan kandungn ion flourida. Adanya ion $\mathrm{Ca}$ dan $\mathrm{HPO}_{4}$ menyebabkan saliva menjadi bersifat supersaturasi yang dalam hal ini dapat menggantikan ion-ion yang hilang dari permukaan gigi akibat peristiwa demineralisasi yang disebabkan oleh asam. Ion $\mathrm{HPO}_{4}$ khususnya mempunyai kapasitas buffer yang signifikan pada awal terjadinya kerusakan permukaan gigi oleh asam., ${ }^{9,11}$

Derajat keasaman saliva tergantung dari perbandingan antara asam dengan kapasitas buffer terutama disebabkan oleh susunan bikarbonat yang naik dengan kecepatan sekresi. Hal ini berarti $\mathrm{pH}$ dan kapasitas buffer saliva juga naik dengan naiknya kecepatan sekresi. Kapasitas cairan buffer dapat didefinisikan sebagai suatu kemampuan untuk menahan perubahan $\mathrm{pH}$. Hal ini di perlukan karena bila mengkomsumsi makanan atau minuman ringan yang asam dapat menurunkan $\mathrm{pH}$ saliva. ${ }^{10,15}$ Konsentrasi bikarbonat pada saliva menentukan $\mathrm{pH}$ saliva. Jadi $\mathrm{pH}$ akan bervariasi bergantung konsentrasi bikarbonat yang ada.

Ada beberapa hal yang mempengaruhi $\mathrm{pH}$ dan kemampuan buffer dari saliva, yaitu usia, diet, irama siang dan malam perangsangan kecepatan ekskresi, jenis kelamin, status psikologis, penyakit sistemik, medikasi tertentu, perubahan hormonal, dan radioterapi. . $^{8,13,14}$

\section{Peningkatan keasaman dalam rongga mulut}

Peningkatan keasaman mulut dipengaruhi oleh aksi buffer dari saliva apabila $\mathrm{pH}$ dalam mulut diatas 5,5 melalui aksi buffer dari saliva maka akan terjadi proses supersaturasi ion $\mathrm{Ca}^{+2}$ dan $\mathrm{PO}_{4}^{-3}$. Pada situasi ini jaringan keras gigi dapat menarik ion atau elemen-elemen yang dikenal sebagai proses remineralisasi. Sebaliknya jika $\mathrm{pH}$ mulut dibawh titik kristis $(\mathrm{pH}<5,5)$, makan akan terjadi subsaturasi ion $\mathrm{Ca}^{+2}$ dan $\mathrm{PO}_{4}^{-3}$ yang menyebabkan kelarutan mineral email gigi kelingkungan dalam mulut yang disebut demineralisasi. Demineralisasi email terjadi melalui proses difusi yaitu terjadinya perpindahan molekul atau ion yang larut dalam air atau dari dalam email ke saliva karena adanya perbedaan konsentrasi dari asam di permukaan dengan di dalam email gigi. ${ }^{1}$

\section{E. Minuman ringan}

Minuman ringan merupakan minuman yg tidak mengandung alkohol/non alkohol. Minuman ringan dengan $\mathrm{pH}$ rendah memiliki potensi merusak struktur gigi. Erosi gigi terjadi ketika seseorang mengkonsumsi minuman yang mengandung zat asam, khususnya asam sitrat dan asam fosfor. Beberapa jenis asam hidroksi organik seperti asam sitrat, asam malat, asam tartarat, asam laktat terdapat hampir disetiap minuman yang memiliki $\mathrm{pH}$ 2,0-3,8. Asam sitrat dan malat terkandung dalam buah-buahan dan makanan yang mengandung buah, sedangakan asam tartarat dijumpai pada buah anggur dan minuman yang mengandung anggur. ${ }^{16,17}$

\section{F. Minuman ringan berkarbonasi}

Minuman ringan berkabonasi adalah minuman yang mempunyai efek extra sparkle dengan ciri khas sentuhan soda di mulut (mouthfeel) dan perasaan yang mengigit (bite) pada saat minuman tersebut diminum. ${ }^{16,17}$ Menurut Ashurt (1998) minuman ringan berkarbonasi adalah minuman yang dibuat dengan mengabsorpsi karbondioksida ke dalam air minum, mengandung gas $\mathrm{CO}_{2}$ yang larut dalam air berfungsi sebagai anti bakteri untuk mengawetkan minuman secara alami. Absorpsi gas $\mathrm{CO}_{2}$ dapat menggunakan alat karbonator. ${ }^{2}$ Asam sitrat dan natrium bikarbonat merupakan senyawa kimia yang utama dalam pembuatan minuman berkarbonasi. Pencampuran asam sitrat dan natrium bikarbonat dapat menimbulkan $\mathrm{CO}_{2}$. Jika asam sitrat dan natrium bikarbonat bereaksi, maka akan terbentuk asam karbonat. Asam karbonat $\left(\mathrm{H}_{2} \mathrm{CO}_{3}\right)$ tersebutlah yang berperan terhadap timbulnya efek extra sparkle dengan ciri sentuhan khas soda di mulut (mouthfeel) dan perasaan yang mengigit (bite) pada saat minuman berkarbonasi diminum. ${ }^{12,16}$

\section{G. Minuman ringan berkarbonasi dan keasaman mulut}

Minuman ringan yang berbahaya bagi enamel adalah minuman yang mengandung karbohidrat yang mudah difermentasi, sangat asam dan mempunyai adesi termodinamik yang sangat tinggi, sehingga minuman ini tidak mudah dihilangkan oleh saliva. Hal ini disebabkan oleh beberapa faktor yang mempengaruhi proses demineralisasi yaitu jenis dan konsentrasi asam minuman yang tidak berdisosiasi, kandungan karbohidrat dalam minuman, $\mathrm{pH}$ dan kapasitas dapar minuman serta kandungan fosfat dan fluor yang ada dalam minuman. ${ }^{8,17}$ Salah satu bagian tubuh yang mampu melindungi enamel gigi dari zat asam adalah saliva. Saliva akan membasahi gigi dengan larutan jenuh yang kaya kalsium dan fosfor, 
sehingga enamel gigi tetap konstan saat demineralisasi struktur gigi terjadi. Selain itu, saliva akan bertindak sebagai buffer untuk mencegah agar rongga mulut tidak terlalu asam. Pada waktu zat asam yang terkandung dalam minuman ringan masuk ke dalam rongga mulut, maka aliran saliva akan meningkat disertai meningkatnya $\mathrm{pH}$, sehingga dalam beberapa saat keasaman dapat dinetralisir dan $\mathrm{pH}$ menjadi normal kembali. ${ }^{7}$

\section{BAHAN DAN METODE}

Jenis Penelitian yang digunakan dalam penelitian ini adalah eksperimental semu dengan pendekatan design group pre-test post-test. Penelitian ini menggunakan sampel sebanyak 50 orang. Saliva dari setiap sampel ditampung lalu di ukur dengan $\mathrm{pH}$ meter, selanjutnya setiap sampel diberi $250 \mathrm{ml}$ minuman ringan berkarbonasi denga rasa orange. Setelah 5 menit, saliva setiap sampel ditampung lagi, kemudian diukur dengan $\mathrm{pH}$ meter. Hasil pengukuran $\mathrm{pH}$ saliva sampel sebelum dan sesudah minum minuman ringan berkarbonasi dicatat.

\section{HASIL DAN DISKUSI}

Berdasarkan hasil penelitian dan pengolahan data, maka pada tabel 1 dapat dilihat adanya perbedaan ratarata $\mathrm{pH}$ saliva sebelum dan sesudah mengkonsumsi minuman ringan berkarbonasi. Rata-rata $\mathrm{pH}$ saliva setelah mengkonsumsi minuman ringan berkarbonasi memiliki rata-rata yang lebih rendah $(6,558)$ dari sebelum mengkonsumsi minuman ringan berkarbonasi $(6,970)$, dengan demikian dapat diketahui adanya penurunan $\mathrm{pH}$ setelah mengkonsumsi minuman ringan berkarbonasi.

Tabel 1 Paired Samples Statistics

\begin{tabular}{lllll}
\hline & Mean N & \multicolumn{2}{c}{ Std. } & Std. Error \\
Deviation & Mean \\
\hline pH Awal & 6.970 & 50 & .1374 & .0194 \\
\cline { 2 - 5 } PH 1 & $\begin{array}{l}\text { Metelah } \\
\text { Mengkonsumsi }\end{array}$ & & & \\
$\begin{array}{l}\text { Minuman } \\
\text { Ringan } \\
\text { berkarbonasi }\end{array}$ & 6.558 & 50 & .1386 & .0196 \\
\hline
\end{tabular}

Hasil pengolahan data menggunakan Paired sample t-test, menunjukkan bahwa terdapat perbedaan yang signifikan antara $\mathrm{pH}$ saliva sampel seblum dan sesudah minum minuman ringan berkarbonasi $(\alpha<0.05)$. Hal tersebut menunjukkan bahwa $\mathrm{pH}$ minuman ringan berkarbonasi secara signifikan memiliki pengaruh terhadap keasaman rongga mulut, yaitu menurunkan $\mathrm{pH}$ saliva.
Table 2 Paired Samples Test

\begin{tabular}{|c|c|c|c|c|c|c|c|c|c|}
\hline & & \multicolumn{5}{|c|}{ Paired Differences } & \multirow{3}{*}{$\mathrm{t}$} & \multirow{3}{*}{ df } & \multirow{3}{*}{$\begin{array}{c}\text { Sig. } \\
(2- \\
\text { tailed) }\end{array}$} \\
\hline & & \multirow[t]{2}{*}{ Mean } & \multirow[t]{2}{*}{$\begin{array}{c}\text { Std. } \\
\text { Deviation }\end{array}$} & \multirow{2}{*}{$\begin{array}{l}\text { Std. } \\
\text { Error } \\
\text { Mean }\end{array}$} & \multicolumn{2}{|c|}{$\begin{array}{l}95 \% \text { Conf. } \\
\text { Interv. of the } \\
\text { Diff }\end{array}$} & & & \\
\hline & & & & & Lower & Upper & & & \\
\hline $\begin{array}{c}\text { Pair } \\
1\end{array}$ & $\begin{array}{l}\mathrm{pH} \text { Awal - } \mathrm{pH} \\
\text { Setelah } \\
\text { Mengkonsumsi } \\
\text { Minuman } \\
\text { Ringan } \\
\text { berkarbonasi }\end{array}$ & .4120 & .1154 & .0163 & .3792 & .4448 & 25.240 & 49 & .000 \\
\hline
\end{tabular}

Teori dari Seow WK menyebutkan bahwa kapasitas cairan buffer dapat didefinisikan sebagai suatu kemampuan untuk penahan perubahan $\mathrm{pH}$. Hal tersebut juga didukung oleh teori dari Barron RP yang mengatakan bahwa susunan kuantitatif dan kualitatif elektrolit di dalam saliva menentukan $\mathrm{pH}$ dan kapasitas buffer. Derajat keasaman saliva tergantung dari perbandingan antara asam dengan kapasitas buffer terutama disebabkan oleh susunan bikarbonat yang naik bersama dengan kecepatan sekresi. Ini berarti $\mathrm{pH}$ dan kapasitas buffer saliva juga naik dengan naiknya kecepatan sekresi.

Pengaruh buffer menyebabkan saliva dapat menahan perubahan asam di dalam rongga mulut. Hal tersebut menunjukkan peranan saliva sebagai faktor proteksi dalam rongga mulut dapat berfungsi dengan baik. Pernyataan tersebut didukung oleh Armasastra yang menyebutkan bahwa saliva mempunyai peranan yang besar dalam proteksi jaringan gigi dari kerusakan karena faktor suasana asam. Faktor protektif yang terkandung dalam saliva adalah ion $\mathrm{Ca}^{2+}$ dan $\mathrm{HPO}_{4}{ }^{2-}$, bikarbonat yang berfungsi sebagai buffer, aliran saliva, dan kandungan ion fluoride. Adanya ion $\mathrm{Ca}^{2+}$ dan $\mathrm{HPO}_{4}{ }^{2-}$ menyebabkan saliva memiliki kemampuan untuk mempertahankan kondisi basa yang dalam hal ini dapat menggantikan ion-ion yang hilang pada permukaan gigi akibat peristiwa demineralisasi yang disebabkan oleh asam.

Berdasarkan hasil penelitian yang telah dilakukan, terlihat adanya pengaruh yang signifikan antara $\mathrm{pH}$ saliva sebelum dan setelah mengkonsumsi minuman ringan berkarbonasi. Hal tersebut kemungkinan karena kapasitas cairan buffer saliva tidak mampu untuk menahan turunnya $\mathrm{pH}$. Jadi bila mengkonsumsi makanan atau minuman ringan yang asam dapat menurunkan $\mathrm{pH}$ saliva atau dengan kata lain dapat meningkatkan keasaman rongga mulut. Penurunan $\mathrm{pH}$ saliva setelah mengkonsumsi minuman ringan juga disebabkan karena minuman ringan berkarbonat memiliki $\mathrm{pH}$ yang sangat rendah atau dibawah $\mathrm{pH}$ kritis sehingga sesudah dikonsumsi menyebabkan terjadinya peningkatan keasaman pada rongga mulut.

Mengkonsumsi minuman ringan yang bersifat asam secara berlebihan akan mengakibatkan terjadinya demineralisasi pada email gigi. Ireland AJ menyebutkan bahwa minuman ringan yang berbahaya bagi enamel 
adalah minuman yang mengandung karbohidrat yang mudah difermentasi, sangat asam dan mempunyai adesi termodinamik yang sangat tinggi, sehingga minuman ini tidak mudah dihilangkan oleh saliva. Amerogen juga mengemukakan bahwa minuman ringan berkarbonat bersifat asam sangat potensial menyebabkan demineralisasi email gigi. Hal tersebut karena asam pada minuman ringan bertindak sebagai selator yang mengikat mineral apatit seperti kalsium. Jumlah garam kalsium yang larut dalam saliva akan sebanding dengan kalsium yang keluar dari saliva dan disimpan dalam email gigi. Pada $\mathrm{pH}$ fisiologis, saliva dan plak bersupersaturasi dengan baik pada hidroksiapatit email. Setelah dikonsumsi, sukrosa akan berdifusi kedalam plak untuk dimetabolisme oleh bakteri didalamnya sehingga menghasilkan asam organik. Produksi ini menyebabkan turunnya $\mathrm{pH}$ dengan cepat $(2-5$ menit $)$ sehingga mencapai nilai dibawah 5 atau 4,5. Ketika pH mengalami penurunan, konsentrasi ion yang dibutuhkan untuk saturasi meningkat, dan dalam rentang $\mathrm{pH}$ sekitar 5,6 jaringan akan mulai larut untuk menjaga saturasi ini. Suasana asam ini akan bertahan cukup lama didalam rongga mulut sebelum akhirnya $\mathrm{pH}$ meningkat secara perlahan kembali ke nilai normalnya (pH 6-7). Menurut Caranza, Brady dan Holum, mekanisme peningkatan $\mathrm{pH}$ saliva oleh kemampuan buffer bikarbonat adalah sebagai berikut: pada kondisi saliva asam, konsentrasi ion $\mathrm{H}^{+}$ saliva akan berlebih, untuk menetralkan kondisi ini maka akan terjadi penambahan konsentrasi bikarbonat. Reaksi antar ion $\mathrm{H}^{+}$dan bikarbonat menghasilkan asam karbonat $\left(\mathrm{H}_{2} \mathrm{CO}_{3}\right)$.

\section{SIMPULAN}

Adanya perbedaan yang signifikan antara $\mathrm{pH}$ saliva sebelum dan setelah mengkonsumsi minuman ringan berkarbonasi adalah akibat kapasitas cairan buffer saliva tidak mampu untuk menahan turunnya $\mathrm{pH}$, sehingga dapat disimpulkan bahwa minuman ringan berkarbonasi dapat meningkatkan keasaman rongga mulut.

\section{DAFTAR PUSTAKA}

1. Ilyas M, Yusri M. Perbedan kadar kalsium dalam saliva sebelum dan sesudah mengkonsumsi minuman ringan yang mengandung asam bikarbonat. Dentofasial 2007;6(2):111-115
2. Ashurst PR. The Chemistry and Technology of Soft Drinks and Fruit Juices. England: Sheffeld Academic Press Ltd.; 1998.

3. Agnes SJ, Widijanto. Peranan berbagai sifat kandungan minuman ringan terhadap potensinya dalam mendemineralisasi gigi. Ceramah Singkat Rimbawanla; 1996. h. 613-9

4. Tarigan R. Karies Gigi. Cetakan IV. Jakarta: Hipokrates; 1995. h. 17-18.

5. Roeslan BO. Imunologi Oral. Cetakan II. Jakarta: Balai Penerbit Fakultas Kedokteran UI; 2002.

6. Faweett, Don W. Buku Ajar Histologi, Tamboyang J (penterjemah), Jakarta: Penerbit EGC; 2002.

7. Amerongen, Van A, Nieuw. Ludah dan Kelenjar Ludah. Yogyakarta: Gadjah Mada University Press; 1991.

8. AI-Saif KM. Clinical Managemenr of Salivary Deficiency. A Review Article The Saudi Dental Journal 1991; 3(2):77-80.

9. Armasastra B. Paradigma Baru Pencegahan Karies Gigi. Jakarta: Lembaga Penerbit Fakultas Ekonomi Universitas Indonesia; 2011.

10. Baron RP, Marcon MA, Sandor KB. Dental erosion gastroesophageal reflux disease. J Can Dent Assoc 2003; 64(2):4-90.

11. Linder MC. Nutritional Biochemistry and Metabolism. 2nd ed. Connectitut: Appleton and Lange; 1991. p. 35-40.

12. Suddick RP, Hyde RJ, Feller RP. Salivary Water and Electrolytes and Oral Health. In: Menaker L (editor). The Biologic Basis of Dental Caries - An Oral Biology Textbook. Maryland; 1980.

13. Kidd EAM, Joyston-Bechal S. Dasar-dasar Karies Gigi Penyakit dan Penanggulangannya, Sumawinata N (penterjemah), Jakarta: Penerbit EGC; 1991.

14. Inoue $\mathrm{H}$, et al. Gender Difference in Unstimulated Whole Saliva Flow Rate and Salivary Gland. Archives of Oral Biology; 2006.

15. Imanuel M, Sulisyawati, Ansori M. Food Science and Culinary Education Journal 2012; 1(1):7

16. Titosuharto. Minuman Ringan Berkarbonasi. Available from: http://titosuharto.wordpress. com /2008/02/25/minuman-berkarbonasi/2008.

17. Ireland AJ, Guinness NM, Sherriff M. An investigation into the ability of soft drink to adhere to enamel. Caries Res 1995;29:470-6. 